\title{
Mariusz Popławski
}

University of Białystok

e-mail: m.poplawski@uwb.edu.pl

ORCID: 0000-0003-1403-3033

\section{OVERVIEW OF THE RECENT CHANGES OF THE POLISH TAX RULES AND SUPPORT FOR TAXPAYER}

\begin{abstract}
The objective of the paper is to present the significance of general rules of tax law resulting from the new draft tax ordinance for the taxpayer's situation. The aim of this paper is to present a general overview of the newly introduced rules of tax law. This study may be the basis for further studies in the field of subject principles. The analysis covered the rules referring to: support of the taxpayer in fulfilling tax obligations, actions of tax authorities in a way that inspires taxpayer's trust, equal treatment of taxpayers, presumption of the taxpayer's honesty, not abandoning the established practice of resolving cases in the same factual and legal state. Within the framework of this paper, research hypotheses concerning the impact of these rules on the legal situation of the taxpayer have been positively verified. These rules will have an impact on the improvement of the taxpayer's situation, which has to face the complicated legal environment. This environment forms the complex tax law system, as well as the intricate and complicated language used by the legislator in making tax law regulations in Poland. This confirms the need to introduce changes resulting from the new draft tax ordinance.

Keywords: tax law, general rules, general rules of tax law, taxpayer's rights, taxpayer's support, tax authority, tax ordinance, new tax ordinance.
\end{abstract}

\section{Introduction}

In Poland, works on a new tax law have been carried out for several years. The establishment of the General Tax Law Codification Committee $^{1}$ was of particular importance in this respect. This entity prepared a draft of this act, which was then proceeded by the Minister of Finance, the Council of Ministers and, as a consequence, was submitted for further work in Parliament ${ }^{2}$. The new tax ordinance ${ }^{3}$ is to replace the tax ordinance of 29 August 1997, which has been in force for over 20 years ${ }^{4}$. The new act will significantly differ from the current tax ordinance 
(Nykiel, Brzeziński, Chróścielewski, Dzwonkowski, Kalinowski, Masternak, Olesińska, 2001, Popławski 2019). It contains almost a dozen or so new institutions which do not currently function in the Polish legal system (Justification, p. 11 et seq.). Among the newly introduced solutions, the general rules of tax law are of particular importance (Bogovac, Soloveva, Radvan, Marczak, Uvarova-Patenko, 2019, Brzeziński, 2001, Brzeziński, Nykiel, 2002, Mariański 2009, Mariański, 2019, Radvan, 2014). At this point it should be noted that the role of rules in law is difficult to overestimate (Eaczkowski, 1989, Ziemski, 1989, Kmieciak, 2000, Gomułowicz, 2001, Gomułowicz, 2003, Mrkývka, 2012).

The newly introduced rules of tax law can be divided into the following types: rules concerning the interpretation of tax law provisions, rules resulting in increasing the effectiveness of the tax authorities, rules concerning the support of the taxpayer and improving the respect of his rights (Popławski [forthcoming]).

The aim of this paper is to present a general overview of the newly introduced rules of tax law, which concern the support for the taxpayer and thereby improve his legal situation and position in relation to the tax authority. This study may be the basis for further studies in the field of subject principles. The following research hypotheses can be pointed out within the framework of this paper. Firstly, these rules will improve the position of the taxpayer in relation to the tax authority. Secondly, these rules will have an impact on the improvement of the taxpayer's situation in the context of a complex legal environment shaped by a complex tax law system and a complex language used by the legislator to shape tax law regulations in Poland. In order to achieve the aforementioned objective of the paper and to verify the research hypotheses, the paper contains separate parts that enable the presentation of certain general rules of tax law, as well as their significance in the context of the legal environment in which the taxpayer is located.

\section{The taxpayer as a weaker entity in relation to the tax authority}

The taxpayer shall be treated as a passive subject of a tax relationship (Mastalski, p. 227). It is confronted with the tax authority, which is an active subject of the tax and legal relationship (Etel, p. 85 et seq.). However, the position of the taxpayer in relation to the tax authority is weaker (Gomułowicz, Mączyński, p. 405 et seq.). The tax and legal relationship is 
characterized by an inequality of entities between which it exists (Popławski, 2019). On the one hand, we deal with a tax authority which has the power to enforce taxes, while on the other hand, the taxpayer is obliged to pay them. The legal nature of a tax legal relationship is similar to that in administrative law, which in turn is considerably different from that of civil law relationships. It is only in the latter case that the two parties are equal in rights and obligations to each other, who can form their mutual rights and obligations on an equal footing. The unequal status of the taxpayer in relation to the tax authority is an important element which may have a negative impact on the taxpayer's situation. Therefore, safeguards should be introduced so that tax authorities do not abuse their privileged position and legal status in relation to the taxpayer.

\section{The taxpayer and the complexity of tax law regulations, tax system and tax cases}

Tax law is a branch of law which is characterized by the fact that it is constantly evolving as it regulates increasingly complex and intricate economic and social phenomena (Etel, p. 42 et seq., Ofiarski, p. 39 et seq., Justification, p. 11 et seq.). The Polish tax system, i.e. all the taxes in force in this state, is also confusing (Pomorski, p. 58 et seq.). The evidence of this is the existence of various taxes, many forms of taxation, their frequent changes, and, at the same time, the existence of EU regulations and international tax law (Gomułowicz, Mączyński, p. 319 et seq., Justification, p. 11 et seq.). It leads to an increase in the complexity of the law, uncertainty as to its content, and thus also to its interpretation and application (Justification, p. 11 et seq.). This is a source of potential conflicts between the interests of taxpayers and the tax administration representing the fiscal interests of the state (Justification, p. 523). Tax issues of taxpayers, which are often the subject of disputes between taxpayers and tax authorities, are also particularly complicated (Mastalski, p. 31). The literature indicates that the complexity of tax cases is the feature that characterizes and distinguishes them from all cases heard by administrative authorities, as tax cases require a number of factual findings or complex evidentiary proceedings (Strzelec, 2008). This applies in particular to taxpayers who have carried out complex economic operations, e.g. transformations, or international transactions or activities. In such cases, even the performance of various activities by taxpayers, including in-depth interpretation of the law, may not 
be sufficient. Regardless of the efforts made by taxpayers, these entities will simply be devoid of legal comfort. They will not be able to be sure whether they did not make mistakes causing certain negative results or tax consequences.

A certain antidote to the complex legal environment functioning in Poland (complex tax law, tax system or tax matters) may be the introduction of tax rules to support this entity. It cannot be considered as a sufficient remedy, e.g. ensuring comprehensive service of taxpayer's tax matters by professional proxies, i.e. persons competent to represent and cooperate with tax authorities (Strzelec, Łoboda, 2017).

\section{The rule of information and support}

Pursuant to Article 16 of the NTO, the tax authorities provide the debtor with information and support in the independent, correct and voluntary performance of his duties and exercise of rights resulting from the provisions of the tax law. In the catalogue of general rules of tax law contained in the draft of the new Tax Code, this rule is already mentioned as the third. This is intended to reflect its high rank (Justification, p. 65 et seq.). On the basis of this rule, the taxpayer should be able to count on information support from the tax authority so that he can thoroughly understand his obligations and rights under the tax law and explain any doubts that may arise in this respect. This is particularly important in the context of complex tax law regulations which the taxpayer has to apply. The support referred to in this provision may also be of a different nature. It can also be said that technical support can be provided by the tax authority for the taxpayer, e.g. assistance in calculating the correct amount of tax, or decision support (e.g. taking into account the taxpayer's request for deferral of tax or payment of tax in installments).

The Justification to the draft NOP indicates that the tax authorities are established to facilitate honest taxpayers' proper fulfillment of their obligation to provide the public authority with cash necessary to meet their collective and individual needs (Justification, p. 65 et seq.). This is in line with the rule adopted in the legal systems of many countries, according to which it should be made easy to comply with the law (and difficult not to comply with it) (Right, 2012). The NTO Justification also argues that information and support should be enforceable not only in tax proceedings and in connection with the subject matter of such proceedings, but should apply to all types of legislation and apply to all tax proceedings (Justifi- 
cation, p. 65 et seq.). It is also underscored that, above all, such actions should be preventive in nature: they should prevent taxpayers from making mistakes before there is a need to assist the party in the course of tax proceedings aimed at verifying and reviewing its accounts (Justification, p. 65 et seq.).

The justification for introducing this rule into the Polish legal system may undoubtedly be the fact that it takes place in declarations of international institutions and acts of other countries. A similar rule has been introduced in the European Code of Good Administrative Behaviour, the European Taxpayers' Code and the Model Taxpayer Charter (Justification, p. 65 et seq.). The Justification to the draft NTO also indicates that the obligation of tax authorities to properly inform taxpayers takes place in many taxpayers' rights charters, e.g. in Ireland, Canada or the USA (Justification, p. 65 et seq.).

\section{The rules of trust, impartiality and equal treatment of taxpayers}

In accordance with Art. 19.1 of the NTO, tax authorities act in a manner that inspires trust and are guided by the rules of impartiality and equal treatment of taxpayers. The essence of the rule according to which tax authorities act in a way that inspires trust is that the state should observe certain rules of honesty in relation to the citizen (Oniszczuk, 2000). In the area of tax law, this rule can be understood as a rule in which the tax authority does not lie, does not deceive, but keeps its promises (Kmieciak, 2000). It is pointed out that the application of the rule of trust excludes the use by tax authorities of ignorance, inexperience and error of the taxpayer (Justification, p. 71 et seq.). Impartiality, on the other hand, means willingness to objectively examine the case on the basis of premises set forth in the tax law and the lack of connection between the tax authority's own interests and any predetermined method of its resolution (Justification, p. 71 et seq.). Impartiality is also the opposite of partiality, i.e. arbitrary preference for the interest of a taxpayer or tax authority in a specific case resolution (Justification, p. 71 et seq.).

The tax authority in its actions towards taxpayers should, as a rule, apply the same standards of conduct towards these entities. However, this rule should apply to taxpayers in similar situations or belonging to groups with certain common qualities. Equal treatment means the same treatment of persons in the same factual and legal situation. Both dimensions of this 
legal requirement are relevant: synchronic (equal treatment should be maintained for taxpayers in a similar situation at a given time) and diachronic (equal treatment should be maintained for taxpayers in a similar situation at different times at different times, assuming the identity of the legal status) (Justification, p. 71 et seq.).

Differentiation in the treatment of taxpayers who are in different situations or belong to different categories seems natural. There is a justification for, for example different treatment of, for example, a microentrepreneur (a taxpayer running a sole proprietorship) and a large taxpayer running a business employing hundreds of people. It is obvious that the affairs of these entities may be different. The former may have a problem with filling in tax returns, while the latter may have a problem with the interpretation of tax law provisions in connection with a transaction with a foreign

entity. The scale and financial consequences of the problems reported by these entities, for obvious reasons, will also most often be different. In such circumstances, we will not be faced with a breach of the rules in question, for instance, when the tax authority devotes several times more of its resources (human, time, financial) to support the other taxpayer. The rules described in this section are replaced by the Code of Good Administration ${ }^{5}$, the European Code of Good Administrative Behaviour ${ }^{6}$, the European Taxpayers' Code?.

\section{The rule of the presumption of the taxpayer's honesty}

Pursuant to art. $19 \S 2$ of the NTO, in their actions tax authorities follow the rule of trust in the debtor, assuming that he acts honestly and in accordance with the law. Tax authorities should therefore choose instruments, solutions, procedures, etc. that will result in the least possible ailments or costs for the taxpayer. The tax authorities should treat irregularities in a taxpayer's action or omission, as a rule, as an unintentional action of this entity. Consequently, the taxpayer should always be able to voluntarily and independently correct its mistakes. Simultaneously, the tax authority should in the first place indicate to the taxpayer the defects in action, and should also present to the taxpayer the ways to resolve them.

Two possible attitudes of tax authorities towards taxpayers are indicated (Justification, p. 73 et seq.). The first type of relationship between a taxpayer and the tax authority - police officers and thieves - is based on the assumption that taxpayers are not prepared to pay what is rightly due 
from them and make efforts to avoid taxes whenever possible and worthwhile (Kirchler, Hoelzl, 2006). The other attitude is related to the assumption that a customer-service provider relationship exists. In such a case, the tax authorities provide the service to the taxpayer. This is related to the assumption that taxpayers are cooperative citizens who, as long as they understand tax law regulations and perceive tax regulations and procedures as legitimate, wish to act in accordance with the law (Kirchler, Hoelzl, 2006).

\section{The rule of legitimate expectations}

Pursuant to Art. 20 of the NTO, the tax authorities do not waive the established practice of resolving cases in the same factual and legal state without a justifiable reason. Currently, taxpayers have many opportunities to learn how the tax authorities interpret certain legal regulations. This is reflected in various documents issued by tax authorities, e.g. tax decisions, court decisions or tax law interpretations (general and individual). So far, however, there is no guarantee that in the event of similar or identical factual and legal situations, which constituted the basis for issuing the aforementioned documents, each taxpayer will be treated in a similar manner. This rule may change this situation in favor of taxpayers. Therefore, it is a rule that may undoubtedly improve the sense of justice and equality before the law of all taxpayers. Thanks to it, a taxpayer may count on treatment similar to that which took place in relation to other entities.

Public authorities will not be able to discretionally form the content of the norms in force and the practice of their application, treating it as an instrument of achieving different goals which they establish discretionally for themselves ${ }^{8}$. Tax authorities will only be able to waive the established practice of resolving cases in the same factual and legal state if the reason is justified, e.g. if the previous practice turns out to be illegal as a result of a decision of the Constitutional Tribunal or if a significant public or social interest is more important (Justification, p. 74 et seq.). It is also pointed out that a tax authority will be bound only by a practice which can be assigned the status of established, which will take place when a practice which is able to raise reasonable expectations in the consciousness of a prudent and properly informed taxpayer that a tax authority will decide a case in a specific manner (Justification, p. 74 et seq.). 


\section{Conclusions}

In the paper both research hypotheses indicated in the introduction were positively verified. The rules provided for in the draft new tax ordinance will therefore improve the position of the taxpayer in relation to the tax authority, and will also have an impact on the improvement of his situation in the context of the complex legal environment in which the entity is located. This is confirmed by the following observations reflected in particular parts of the work.

Firstly, the legal situation of the taxpayer in relation to the tax authority is characterized by the inequality of these entities to the detriment of the taxpayer. For this reason, security mechanisms should be introduced so that the tax authorities do not abuse their privileged position and legal status in relation to the taxpayer.

Secondly, the taxpayer has to deal with a complex legal environment formed by intricate tax law, complex tax system and complex tax matters, as well as the uncommunicative and confusing language used by the legislator in making tax law in Poland.

Thirdly, as a consequence of the introduction of the rule of information and support, the taxpayer should receive information support from the tax authority (this rule will enable the taxpayer to better know his rights and obligations and will also help to clarify any doubts that may arise in this respect), technical support (e.g. assistance in calculating the correct amount of tax), decision support (e.g. taking into account the taxpayer's applications in favor of the taxpayer).

Fourthly, as a result of the rule of trust, the tax authority must not mislead the taxpayer and must also keep its promises. In connection with the rule of impartiality, the taxpayer will be able to rely on the tax authority, when deciding on the taxpayer's case, to do so objectively without adopting a predetermined manner of resolving it. The introduced rule of equality will cause that the tax authority in its actions towards taxpayers in the same factual and legal situation should therefore apply the same standards of conduct towards these entities.

Fifthly, the application of the rule of presumption of taxpayer's honesty will mean that the tax authorities in their actions towards taxpayers should: choose instruments that will result in the least possible discomforts and costs for the taxpayer, indicate to taxpayers defects in their actions, present taxpayers with proposals and methods of correcting errors committed by taxpayers, and thus enable taxpayers to voluntarily and independently correct errors made by them. 
Sixthly, the introduction of the rule of legitimate expectations into tax law will result in the taxpayer being able to expect treatment similar to that applied to other entities. Tax authorities will be able to waive the established practice of resolving cases in the same factual and legal situation only in exceptional cases.

\section{N O T E S}

${ }^{1}$ Regulation of the Council of Ministers of October 21, 2014 on the foundation, organisation and operation of the General Tax Law Codification Committee (Dz. U. item 1471 as amended).

2 https://legislacja.rcl.gov.pl/docs//2/12314054/12523424/dokument399176.pdf access: Sept. 1, 2019.

3 Hereinafter also referred to as NTO or the new tax ordinance.

4 i.e. Dz.U. of 2015 item 613 as amended; hereinafter referred to as t.o.

5 That act indicates, inter alia, that the public authority should act in accordance with the principle of impartiality, objectively and having regard only to the relevant matters, and that it should not act in a biased manner. In accordance with the principle of equality under that Code tax authorities should treat taxpayers who are in the same situation in the same way. They should not discriminate between natural persons on grounds such as sex, ethnic origin, religious or other beliefs.

${ }^{6}$ According to the Code. the authority should act impartially and independently, refraining from any arbitrary actions that may have a negative impact on the situation of individuals and from any form of favoritism, regardless of the motives behind such actions.

7 The act indicates, inter alia, that taxpayers may expect the tax authority to perform its functions in a neutral manner and free from any undue influence.

8 Compare the ruling of the Constitutional Tribunal of October 15,2008 , on case P32/06, OTK Z.U. 2008, no 8A, item 138, point III.3 of the justification.

\section{R E F E R E N C E S}

Bogovac, J., Soloveva, N., Radvan, M., Marczak J., Uvarova-Patenko, N. (2019) Tax Administration of Large Taxpayers in Some CEE and CIS Countries. Public Governance, Administration and Finances Law Review in the European Union and Central and Eastern Europe, Budapest: Nordex Non-Profit Ltd., vol. 2018, no. 2, p. 5-27. ISSN 2498-6275.

Brzeziński, B. (2001) Kierunki zmian przepisów ogólnych Ordynacji podatkowej, "Kwartalnik Prawa Podatkowego" , nr 3-4. (Directions of changes in general provisions of the Tax Ordinance)

Brzeziński, B., Nykiel, W. (2002) Zasady ogólne prawa podatkowego, "Przegląd Podatkowy", nr 3. (General rules of tax law)

Etel, L. (2013), (ed.) Prawo podatkowe. Zarys wykładu, Warszawa. (Tax law. Intruduction). 
Gomułowicz, A. (2001) Zasady podatkowe wczoraj i dziś, Warszawa. (Tax rules yesterday and today)

Gomułowicz, A. (2003) Zasada sprawiedliwości podatkowej w orzecznictwie Trybunału Konstytucyjnego, Warszawa. (The rule of tax justice in the rulings of the Constitutional Tribunal)

Gomułowicz, A., Mączyński, D. (2016) Podatki i prawo podatkowe, Warszawa. (Taxes and tax law).

Kirchler, E., Hoelzl, E., (2006) Modelling Taxpayers' Behaviour as a Function of Interaction between Tax Authorities and Taxpayers (in:) H. Elffers, P. Verboon, W. Huisman, Managing and Maintaining Compliance, Hague.

Kmieciak, Z. (2000), Ogólne zasady prawa i postępowania administracyjnego, Warszawa. (General rules of law and administrative procedurę)

Łączkowski, W. (1989) Zasady podatkowe w orzecznictwie polskiego Trybunału Konstytucyjnego (in:) J. Małecki (ed.), Koncepcje współczesnych reform podatkowych. Europa na drodze do wspólnej waluty, Książka wydana z okazji 40-lecia pracy naukowej prof. dr. hab. Andrzeja Komara, Poznań. (Tax rules in the rulings of the Polish Constitutional Tribunal /in:/' J. Małecki /ed./ Concepts of modern tax reforms. Europe on the road towards current currency).

Mariański, A. (2009) Rozstrzyganie wątpliwości na korzyść podatnika. Zasada prawa podatkowego, Warszawa (Resolving doubts in favor of the taxpayer. The rule of tax law).

Mariański, A. (2019) Zasady ogólne prawa podatkowego - teoria i praktyka (in:) Współczesne problemy prawa podatkowego. Teoria i praktyka. Tom I, Księga Jubileuszowa dedykowana Profesorowi Bogumiłowi Brzezińskiemu, Warszawa. (General rules of tax law: theory and practice /in:/ Current problems of tax law. Theory and practice)

Mastalski, R. (2018) Prawo podatkowe, Warszawa (Tax Law).

Mrkývka, P. (2012) Determinace a diverifikace finančního práva. 1. ed. Brno: Masarykova univerzita. Acta Universitatis Brunensis No 436.

Nykiel, N., Brzeziński, B. Chróścielewski, W., Dzwonkowski, H., Kalinowski, M., Masternak M., Olesińska A. (2001) Projekt przepisów ogólnych Ordynacji podatkowej. Kwartalnik Prawa Podatkowego, No. 3-4. (The draft of general provisions of the Tax Ordinance).

Oniszczuk, J. (2000) Konstytucja Rzeczypospolitej Polskiej w orzecznictwie Trybunału Konstytucyjnego, Kraków. (The Constitution of the Republic of Poland in the rulings of the Constitutional Tribunal).

Ofiarski, Z. (2013), Ogólne prawo podatkowe. Zagadnienia materialnoprawne i proceduralne, Warszawa. (General tax law. Substantive and procedural issues).

Pomorski, P. (2019), System podatkowy i jego uwarunkowania, (in:) Smoleń P. ed. Prawo podatkowe, Warszawa. (Tax system and its relations /in:/ Smoleń P., ed., Tax Law. 
Popławski, M. The impact of general tax law rules contained in the new tax ordinance act on the interpretation of tax law. Zeszyty Naukowe Uniwersytetu Rzeszowskiego, Seria Prawnicza, (forthcoming),

Popławski, M. (2019). Komentarz do art. 7, (in:) Etel L. red. Ordynacja podatkowa. Komentarz, Warszawa. (A comment on Article 7 /in:/ Etel L., ed., The Tax Ordinance. A comment).

Radvan, M. (2014) Tax Law as an Independent Branch of Law in Central and Eastern European Countries. Lex Localis - Journal of Local Self-Government, Maribor, Graz, Trieste, Split: Institute for Local Self-Government and Public Procurement Maribor, vol. 12, no. 4, pp. 813-827. ISSN 1581-5374. doi: 10.4335/12.4.813-827(2014). WoS: 000343688000004.

Right from the Start: Influencing the Compliance Behaviour for Small and Medium Enterprises, Forum on Tax Administration, OECD 2012, http://www.oecd. org/site/ctpfta/49428016.pdf.

Strzelec, D. (2008) Eliminowanie nieprawidłowości proceduralnych przez organ odwoławczy a zasada dwuinstancyjności postępowania, "Monitor Podatkowy", nr 5 (Eliminating procedural defects by the appeal authority and the rule of double-instance procedurę).

Strzelec, D. (2015), O potrzebie badań prawnoporównawczych w obszarze procedury podatkowej, "Przegląd Podatkowy", nr 8. (On the need for legal comparative studies on tax precedure).

Strzelec, D. Łoboda M. (2017) Kontrola przestrzegania przepisów prawa podatkowego, Warszawa, s. 129 (Inspection of abiding the provisions of tax law).

Uzasadnienie do projektu ordynacji podatkowej, https://legislacja.rcl.gov.pl/docs// 2/12314054/12523424/dokument399176.pdf - dostępne w dniu 1.09.2019 r. (Justification of the draft Tax Ordinance)

Ziemski, K. (1989) Zasady ogólne prawa administracyjnego, Poznań. (General rules of administrative law). 